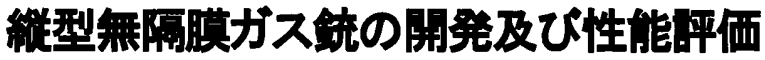

\author{
江川祐也 ${ }^{* 1}$, 梅田晃樹 ${ }^{* 1}$, 渡辺圭子 ${ }^{* 2}$

\section{Development and Performance Evaluation of Diaphragmless Vertical Gas Gun}

\author{
Yuya EGAWA ${ }^{* 3}$, Kohki UMEDA and Keiko WATANABE \\ *33 Department of Mechanical Engineering, Ritsumeikan University \\ 1-1-1 Nojihigashi, Kusatsu, Shiga, 525-8577 Japan
}

\begin{abstract}
Crushing compression test of sand has been done under static loading conditions in the fields of geotechnology. However, measurement method of experiment has not been established at high speed impact due to the various parameters of sand (grain diameter, density, material, moisture content) which make it more complicated. The development and performance evaluation of projectile accelerator for high speed experiment had been performed for the study of crushing phenomenon of the sand. The diaphragmless vertical gas gun do not use the diaphragm that will affect the experiment had been developed and is able to handle target material with fluidity.
\end{abstract}

Key Words : Gas Gun, Diaphragmless, Vertical

\section{1. 料}

かつて砂は破砕しないものと考えられており，巨 大構造物が建設されてきた. しかし，近年では砂の 破砕の影響を考慮した研究が地盤工学において進ん でいる(1). 砂の破砕試験は単粒子と集合体に分け行 われている．単粒子の破砕においては一軸圧縮試験 機を用い，集合体の破砕においては三軸圧縮圾験機 を用い評価する方法が一般的であり，静的負荷での 砂一の破砕試験は多々報告されている. しかし，高 速衝突に扔ける砂の破砕試験は応力や強度の測定が 困難であることや，砂自体のパラメータ（粒径，密 度, 砂粒子の材質, 含水率) が多く複雑なため研究 が進んでいない，そのため，物体の高速衝突・貫入 における粒子破砕の研究は非常に意義がある.

高速試験を行うには高速で物体を発射させる飛翔 体加速装置が必要となる. 飛翔体加速装置にはガス 銃，火薬銃，二段式軽ガス銃などの種類があり，対 象となる速度やターゲットなどにより使用する装置 を選別する必要がある. 今回は最大 $500 \mathrm{~m} / \mathrm{s}$ での試 験を想定しているため, ガス銃を選択した. 飛翔体

\footnotetext{
${ }^{* 1}$ 学生員, 立命館大学大学院理工学研究科

（テ525-8577 滋賀県草津市野路東 1 丁目 1-1)

2 2 正員, 立命館大学

E-mail: rm0014re@ed.ritsumei.ac.jp
}

加速装置は加速距離を長く取る必要があるため, 空 閒的制限の少ない横型の装置が一般的である. しか し，ターゲットとして流体的挙動を示す砂を扱うた め縦型である必要がある．また，隔膜によりガスを 高圧に保ち，その破膜により飛翔体を加速するのが 一般的であるが，その方法では隔膜の衝突により試 験後の砂層の状態を変化させ, 試験結果に影響を及 ぼす可能性がある，そこで，縦型無隔膜ガス銃の開 発及び性能評価を行った。

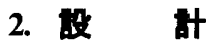

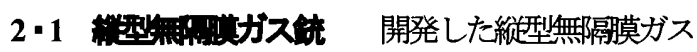
銃は一般的なガス銃と同じく高圧室，加速管，圾験室で 構成されている(図 1)。しかし，大きく異なる点が二 つある. 一目は縦型という点である. 縦型にすること で流体や砂などの流動物質を扱うことができる. 二つ目 は無融莫という点である. 通常は高圧室と加速管を遮断 するのに隔膜を使用する．隔膜の破断圧を超える圧力が かかると，隔膜は破断して飛翔体後部に高圧ガスが流れ 込み，飛翔体は加速される，その際，隔膜も一緒に飛ば されるため試験結果に影響を及ぼしてしまうことがある。 そこで隔膜を使用しない方法を考案した. 高珐部断面の 概略図を図 2 に示す。これは隔膜の代わりにピストンを 用いて高圧室と加速管を遮断する力法である. 高圧室 (オ レンジ色領域) と補助高玨室 (青色領域) の圧力が一定 
に保たれているときは遮断されているが，補助高圧室の 高圧ガスを一気に排気することにより，ピストンが図 2 の知印方向に後退する，それにより飛翔体後部一一気に 高圧ガスが流れ込み，飛羴体か加速するという仕組みで ある. また，ピストンを用いることで使い捨ての隔膜と は違い，繰り返し使用できるため作業効率が上がると共 に，環竟負荷が低くなるという利点もある。

飛翔体の最高速度が $500 \mathrm{~m} / \mathrm{s}$ 以上となるように，以 下の方法で部品サイズを決定した. 飛翔体速度 $v$ を決

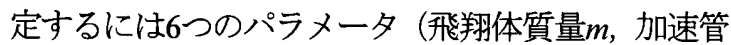
断面積 $S$, 高圧室ガス圧 $P_{0}$, 高圧室容積 $V_{0}$, ガス比熱 比 $y$, 飛翔体初期設置位置からの移動距離x）がある. 次の3つの方程式（1）～(3)

運動方程式

$$
m \frac{d v}{d t}=S P_{0}
$$

状態方程式 (断熱変化)

$$
P(x) V^{\gamma}(x)=P_{0} V_{0}^{\gamma}
$$

飛翔体背後の空間容積

$$
V(x)=V_{0}+S x
$$

より，飛翔体速度 $v$ を求める式は次のようになる.

$$
v=\sqrt{\frac{2 P_{0} V_{0}^{\gamma}}{m(\gamma-1)}\left\{V_{0}^{-\gamma+1}-\left(V_{0}+S L\right)^{-\gamma+1}\right\}}
$$

式 (4) は理論的な飛翔体速度であり, 実際は摩擦 等の影響を受けるため経験上8割程度の速度になる.

これまでの研究条件との統一性のため, 飛翔体の質量 $m$ を $16 \mathrm{~g}$, 飛翔体の直径 (加速管内径) を $15 \mathrm{~mm}$ に決定 した. また構造上の制約として，加速管長さと高圧室高 さの合計は $3 \mathrm{~m}$ 以下にする必要があった．高圧室の最大 ガス圧を $10 \mathrm{MPa}$ ，使用ガスを窒素ガスとし，計算の結果， 高圧室容積を $5.09 \times 10^{-3} \mathrm{~m}^{3}$, 加速管長さを $2 \mathrm{~m}$ と決定した (表 1 参照)．以上の機構で式 (4) より速度は理論上 $625 \mathrm{~m} / \mathrm{s}$ ，害祭の速度は $500 \mathrm{~m} / \mathrm{s}$ となる予定である.

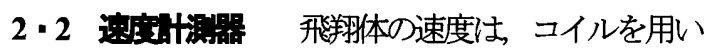
た非接触型の速度計測器を加速管先端部に取り付けて計 測した. その楖略図を図 3 に示す. $20 \mathrm{~mm}$ 間隔て設置し たコイルに磁石を搭載した飛翔体が通過するときに発生 する誘導起電力をオシロスコープで取得する. オシロス
コープの波形より飛翔体がコイル間距離を移動するのに 要した時間を求め, コイル間の距離から飛释体速度を算 出できる仕組みである.

Table 1 Design parameters

\begin{tabular}{|l|l|}
\hline Projectile mass: $m[\mathrm{~g}]$ & 16 \\
\hline Cross-sectional area of launch tube: $S\left[\mathrm{~m}^{2}\right]$ & $1.77 \times 10^{-4}$ \\
\hline Gas specific heat ratio (nitrogen): $\gamma$ & 1.402 \\
\hline Maximum gas pressure: $P_{0}[\mathrm{MPa}]$ & 10 \\
\hline Volume of high pressure chamber: $V_{0}\left[\mathrm{~m}^{3}\right]$ & $5.09 \times 10^{-3}$ \\
\hline Length of launch tube $[\mathrm{m}]$ & 2 \\
\hline
\end{tabular}

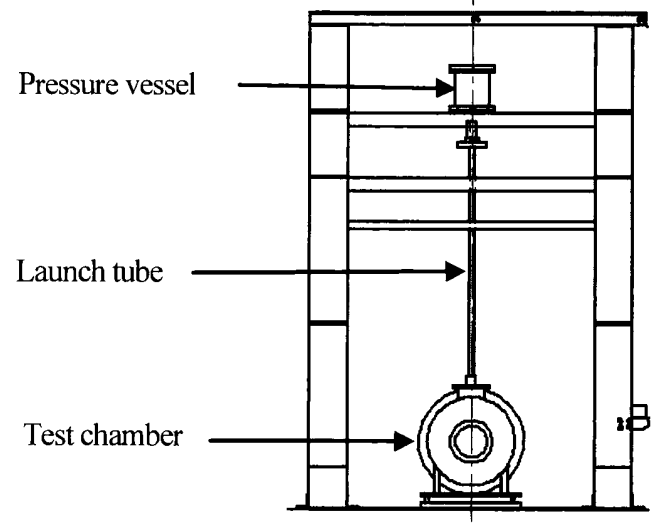

Fig. 1 Schematic diagram of gas gun

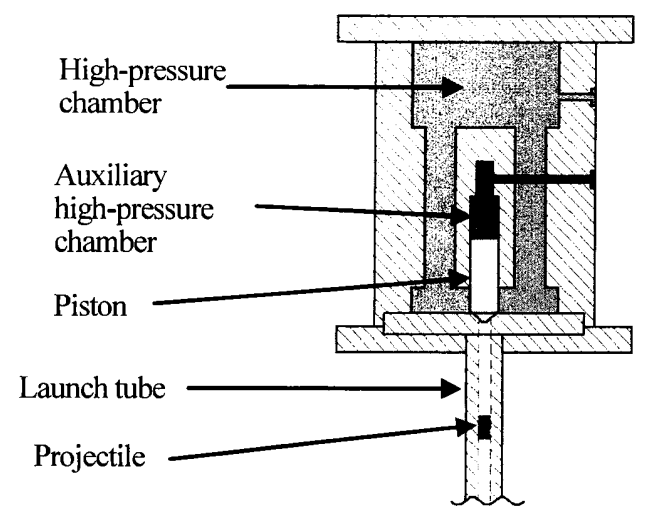

Fig. 2 Schematic diagram of pressure vessel

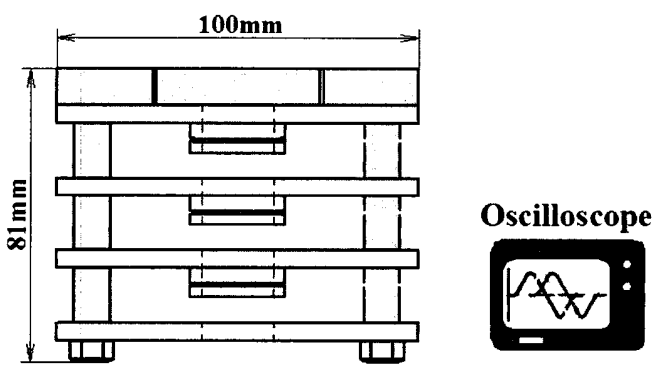

Fig. 3 Speed measuring instrument 
また，各コイルの上方には板が設置されており， 飛翔体を駆動する高圧ガスがターゲットに到達する のを阻止するバッファの役割を果たしている．さら に，最下部にはアルミ板が設置されており，ターゲ ットからの噴出物や飛翔体破壊時の破片から速度計 測器を保護するシールドの役割を果たしている.

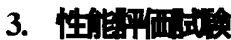

性能評価を行う点は主に二つある. 一つ目は目標速度 である. 設計時に用いた飛翔体速度 $v$ を求める式 (4) は 理論式であり経験則を用いて目標最高速度を $500 \mathrm{~m} / \mathrm{s}$ に 設定したが，期待する速度が出ない可能性もある．目標 速度を達成するために性能師平価試験て変更するパラメー 夕はいくつかあるが(2)(3)，これまでの詿験の統一性のため 今回は飛翔体の外径寸法を変更し速度への影響を評価す る. 性能評価試験に使用する飛䍩体を図 4 に示寸，実際 の試験之条件を揃えるため，性能評価用飛翔体の質量・ 寸法を試験用飛翔体と同様にした，飛翔体はインパクタ 部分と胴部分の 2 層構造になっており, 速度計測のため 飛翔体最後部にネオジム磁石を搭載している，重心か榌 翔体の中心に位置するとターゲット衝突時に飛翔体が傾 いて貫入してしまい，試験を正確に行うことができない 恐れがあるため，重心は前方に位置する必要がある，そ こでインパクタ部分に黄銅を，胴部分に比重が軽し 部 材を使用し，重心を飛翔体先端から約 $6 \mathrm{~mm}$ の位置に設 定し飛翔体の姿勢を安定させた。

飛翔体外径は $15 \mathrm{~mm}$ から $0.01 \mathrm{~mm}$ ずつ寸法を減少させ 各寸法に対して試験を行う. そのため, 飛翔体外径と加 速管内径はほほ同じ寸法となり，飛翔体を加速管に押し 込むように設置しなくてはならない，そのため，飛翔体 胴部分に硬、材料を使用すると加速管内壁がダメージを 受ける．また，飛翔体外径を小さくすると加速管内部の シールド性が低下する．そこで，加速管内壁のダメージ を減少させ，発射時に高圧で負荷がかかることにより胴 部分が広がりシールド性を高めることができるポリエチ レンを使用した。

二つ目は速度制御である. 速度制御はガスの圧力によ り行う. ガスの圧力を正確に制御するための装置を図 5 に示す．図 5 の操作パネルにより高王室・補助高圧室に 出力されたそれぞれの高圧ガスの圧力は圧力容器付近に 設置されている圧力変換器により測定する. そして, 測 定された圧力は図 5 右下の郝部分によりデジタル表記 し，正確に読み取ることができる. しかし，正確に同じ 圧力を高圧室に出力しても速度が一定にならず，高速に なるにつれ速度誤差が徐々に大きくなる.この速度誤差 は圾験結果に直接影響するため，可能な限り少なくする
必要がある. そこで, 本装置では速度誤差の目標数值を $5 \%$ 以下とし，速度に対する性能評価を行うこととした。

\section{辞}

本研究は, JSPS 科研費 24560978 の助成金を受けたも のであり, ここに記して謝意を表する.

\section{文献}

(1) Shahnazari, H. and Rezvani, R, Effective Parameters for the Particle Breakage of Calcareous Sands: An Experimental Study, Engineering Geology, Vol. 159 (2013), pp. 98-105.

(2) Yokoo, M., Kawai, N., Nakamura, K.G. and Kondo K., Hugoniot Measurement by Hyper-Velocity Impact at Velocities up to $9 \mathrm{~km} / \mathrm{s}$ Using a Two-Stage Light-Gas Gun Under Optimized Shot Conditions, International Journal of Impact Engineering, Vol.35, No.12 (2008), pp. 1878-1883.

(3) Francesconi, A., Pavarin, D., Bettella, A. and Angilli, F., A Special Design Condition to Increase the Performance of Two-Stage Light-Gas Guns, International Journal of Impact Engineering, Vol.35, No.12 (2008), pp. 1510-1515.

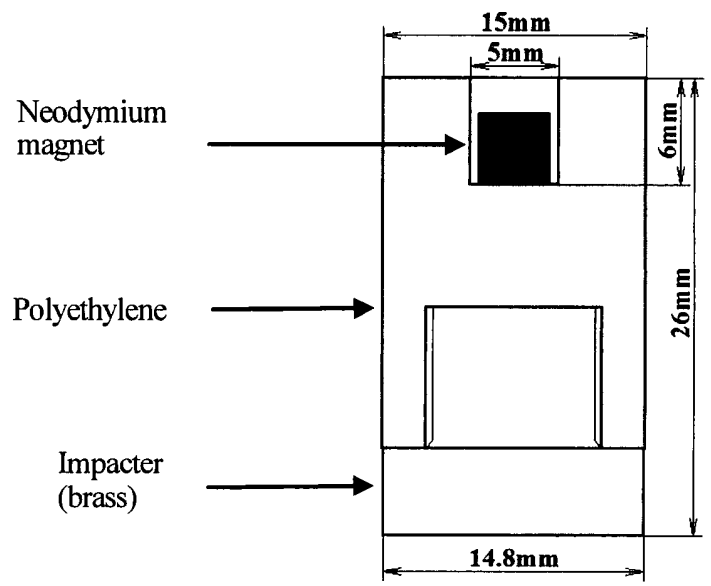

Fig. 4 Projectile for performance evaluation

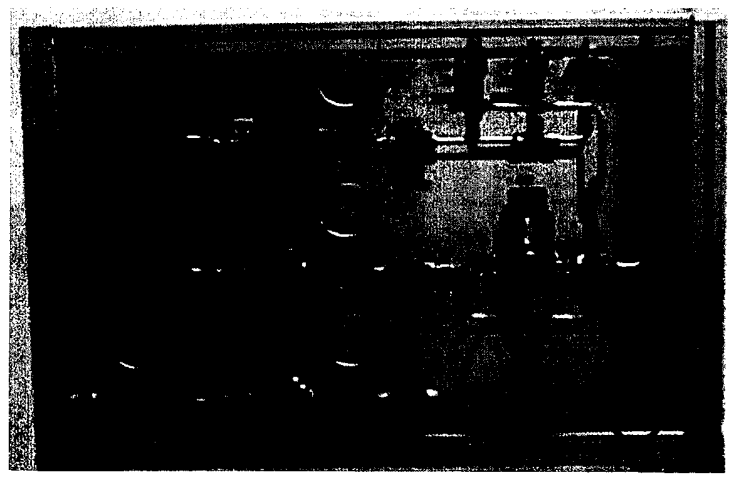

Fig. 5 Operation panel 